\title{
Integrasi Manajemen Perubahan pada Proyek Lean Six Sigma dalam Peningkatan Mutu dan Kinerja Perusahaan
}

\author{
Ayesha Gilang Prahara1, Catharina Bada Nawangpalupi ${ }^{2}$ \\ 1,2) Fakultas Teknologi Industri, Jurusan Teknik Industri, Universitas Katolik Parahyangan \\ Jl. Ciumbuleuit 94, Bandung 40141 \\ Email: ayeshgilang@gmail.com, katrin@unpar.ac.id
}

\begin{abstract}
$P T X$ is a small enterprise producing various types of jute fabric products. As a traditional business, the company still largely rely on the handiness and crafting skills from their workers. Whilst the business competition increases, PT $X$ requires to strengthen the business by improving product quality in an efficient way. Besides high level of defects, PT X has also non-value-added activities in their production resulting in high overtime hours of their workers. Although PT X considers the overtime is acceptable to achieve the production target, there is room for improvement to reduce the defects as well as to shorten the production lead time. This paper aims to tackle the inefficiency and quality of the company. Lean six sigma is proposed to improve the condition and change management is implemented to ensure the commitment and participation of all staff for the success of change. Hence, this paper proposes the combination of change management and lean six sigma to improve production quality, lead time and staff participation. Combining DMAIC methods with change management, a methodology called $D M A(C) I C$ is used with the middle $C$ is for change. The implementation of the integration between change management in lean six sigma has resulted in the reduced number of defects and shorter lead time and the awareness of the workers to improve their working behavior.
\end{abstract}

Keywords: change management, lean six sigma, defects, DMAIC, quality improvement

\begin{abstract}
Abstrak
PT X merupakan usaha kecil yang memproduksi berbagai jenis olahan kain goni. Sebagai usaha yang bersifat tradisional, perusahaan masih menekankan pada kemampuan kerajinan tangan yang didasarkan pada keahlian para pekerjanya. Dengan meningkatnya kompetisi usaha, PT X harus terus memperkuat usahanya dengan meningkatkan mutu produk secara efisien. PT X masih memiliki jumlah cacat produk yang tinggi disertai waktu produksi yang panjang. Banyaknya aktivitas yang tidak memberikan nilai tambah membuat para pekerja di PT X sering lembur. Meskipun PT X menganggap hal tersebut biasa dan tidak menjadi prioritas sejauh target produksi tercapai, terdapat ruang untuk perbaikan dalam permasalahan ini. Artikel ini bertujuan untuk memetakan permasalahan efisiensi dan peningkatan mutu produk secara sekaligus. Lean six sigma digunakan untuk menyelesaikan permasalahan ini dan manajemen perubahan digunakan untuk memastikan komitmen dan partisipasi seluruh pegawai dari setiap lini untuk keberhasilan perubahan. Oleh karena itu, integrasi manajemen perubahan dalam proyek lean six sigma ditawarkan agar perusahaan dapat memperbaiki mutu, waktu produksi dan partisipasi pegawai secara menyeluruh. Metodologi yang mengombinasikan DMAIC dengan manajemen perubahan digunakan dengan metodologi yang disebut DMA(C)IC, dengan $\mathrm{C}$ di tengah berarti "change". Implementasi integrasi manajemen perubahan dalam lean six sigma menghasilkan penurunan cacat, waktu produksi dan peningkatan kesadaran pegawainya untuk memperbaiki kondisi kerjanya.
\end{abstract}

Kata kunci: manajemen perubahan, lean six sigma, cacat, DMAIC dan perbaikan mutu 


\section{Pendahuluan}

Di bumi ini segalanya pasti selalu berubah. Perubahan tersebut meliputi setiap individu, organisasi bahkan alam pun akan mengalami perubahan. Demikian yang terjadi pada perusahaan, perusahaan akan hanya bertahan jika mampu melakukan suatu perubahan. (Robbins, 2001) menyebutkan semua perubahan yang dilakukan mengarah pada peningkatan efektivitas organisasi dengan tujuan mengupayakan perbaikan kemampuan organisasi dalam menyesuaikan diri terhadap perubahan lingkungan serta perubahan organisasi, perubahan organisasi dapat dilakukan pada struktur yang mencakup strategi dan sistem, teknologi, penetapan visi dan sumber daya manusia maka dari itu perlu adanya usaha guna menciptakan perubahan ke arah yang lebih baik lagi.

Perubahan tidak selamanya berdampak baik, adapun perubahan yang berdampak buruk, seperti halnya perusahaan-perusahaan besar dulu berkembang dengan pesat, namun tidak muncul lagi di masa sekarang. Berdasarkan laporan bulanan BPS tahun 2015 industri mikro, kecil dan menengah menunjukkan kenaikan yang signifikan dari tahun sebelum. Hal ini memberikan dampak signifikan terhadap daya saing industri-industri kecil menengah di tengah persaingan yang sangat tinggi pada era ini. Kebutuhan yang sangat beragam menuntut perusahaan agar terus memenuhi standar kualitas dari konsumen guna melanjutkan roda suatu organisasi perusahaan tersebut.

PT $X$ tergolong ke dalam perusahaan yang tradisional, dimana segala hasil produksinya masih ditentukan oleh tangan kreativitas para pekerjanya. Kegiatan utamanya yaitu mengolah kain goni menjadi berbagai macam produk yang memiliki nilai jual lebih tinggi. Kemudian dalam penelitian ini fokus penelitian kepada 3 produk utama yaitu tas jinjing, tas jinjing bergambar dan karung kopi.

Dalam proses produksinya PT $X$ ini masih terdapat permasalahan yang harus dihadapi. Salah satu masalah yang sering terjadi yaitu defect product yang secara konsisten terus dihasilkan setiap proses produksi. Terdapat sebanyak $32 \%$ produk cacat pada produk karung kopi atau sebanyak 503 produk cacat dari total produksi 1950 produk yang diamati. Melihat banyaknya produk cacat yang dialami oleh PT X merupakan hal yang lumrah bagi mereka, sehingga permasalahan yang jelas tergambarkan dalam PT $X$ ini adalah kurangnya kesadaran rasa ingin berubah, tidak reaktif menyikapi permasalahan, bahkan tidak adanya rasa urgensi dari para pekerja maupun pemimpin dari perusahaan mengakibatkan PT $X$ tidak sulit berkembang.

Banyaknya waste yang dihasilkan dan kurangnya kesadaran untuk berubah menjadi permasalahan utama dalam perbaikan penelitian ini.

Menurut (Pyzdek, 2003), organizational traditional thinking's akan melakukan perubahan jika mereka sudah mengalami tanda bahaya, masalah, ataupun krisis terhadap perusahaan mereka. PT $X$ merupakan salah satu industri yang harus bereaksi terhadap perubahan-perubahan yang terjadi. Di tengah daya saing yang tinggi, PT $X$ dituntut terus berkembang guna terus menjadi perusahaan yang efektif dan efisien dalam memenuhi konsumennya.

Adapun beberapa penelitian terdahulu yang dilakukan oleh beberapa peneliti mengenai proyek perbaikan dan manajemen perubahan. Noori \& Latifi (2018) menyebutkan bahwa proyek perbaikan kualitas harus disisipkan aspek manajemen perubahan. Penelitian Noori \& Latifi menunjukkan bahwa pengembangan model berbasis manajemen perubahan mampu mempercepat implementasi proyek. Selain itu, penerapan manajemen proyek dapat mengurangi resistensi individu, kelompok, maupun organisasi pada lingkungan tersebut. Teknik manajemen perubahan tersebut disisipkan pada metode DMAIC (Define - Measure - Analyse - Improve Control), sehingga menghasilkan DMA(C)IC. C yang disisipkan di antara analyze dan improve adalah change management.

Lertwattanapongchai \& Swierczek (2014) menjelaskan bahwa beberapa indikator keberhasilan penerapan proyek perbaikan kualitas merupakan komponen dari teknik manajemen perubahan, sehingga metode manajemen perubahan dianggap sangat penting dalam pelaksanaan program proyek perbaikan kualitas.

Terkait pengembangan proyek lean six sigma, banyak peneliti yang membuktikan perlunya kedua metode tersebut untuk digabungkan. Pepper \& Spedding (2010) menjelaskan dalam proyek perbaikan kualitas, 
filosofi lean dan six sigma merupakan suatu metode yang melengkapi satu sama lain. Penerapan lean atau six sigma saja ditengarai oleh Arneither \& Maleyef (2005) tidak terlalu efektif jika diterapkan secara luas dalam organisasi. Selain itu, Salah, Rahim, \& Carretero (2010) menyebutkan bahwa lean six sigma merupakan metode yang saling melengkapi dan diterima secara luas oleh perusahaan yang mengejar keunggulan operasional dan layanan. Kedua metode tersebut akan menghasilkan metode yang sangat kuat ketika mereka saling berintegrasi.

Penerapan manajemen perubahan merupakan hal yang sangat relevan dalam transformasi dan proyek perbaikan. Gupta (2011) menjelaskan secara rinci relevansi proses transformasi model perubahan (Lewin, 1951) maupun (Kotter, 1995) dengan perubahan organisasi. Gupta menegaskan kekuatan model perubahan Kotter maupun Lewin yang dapat digabungkan dalam sebuah matriks. Pada pendidikan tinggi, Hess \& Benjamin (2015) menyatakan bahwa penerapan lean six sigma di mempengaruhi perubahan budaya, sejauh adanya pengelolaan bersama dan partisipasi dosen dan karyawan. Studi empiris yang dilakukan Hudnurkar \& Ambekar (2019) menunjukkan bahwa kegagalan proyek Six Sigma diakibatkan karena dukungan manajemen yang lemah, kurangnya pengelolaan perubahan dan belum matangnya organisasi.

Berdasarkan studi terdahulu yang kontekstual dengan permasalahan yang terjadi di PT $X$, perlu adanya perbaikan dengan metode yang tepat. Pendekatan lean six sigma diharapkan dapat digunakan untuk analisis perbaikan serta mengurangi waste yang dihasilkan di PT $X$ salah satunya yang menjadi masalah utama yaitu defect product. Kemudian, pendekatan manajemen perubahan diharapkan menjadi gaya pendorong proyek perbaikan yang akan dilakukan di PT $X$, sehingga kedua metode ini dapat menjadi metode yang tepat untuk menjawab permasalahan yang ada di PT X. Berdasarkan paparan hasil identifikasi yang telah dijabarkan, maka dapat dibuat beberapa rumusan masalah yaitu hal apa saja yang perlu dilakukan dalam menerapkan manajemen perubahan terhadap proyek lean six sigma, pengaruh terhadap proyek perbaikan, dan perbandingan kondisi sebelum perbaikan dan setelah perbaikan.

\section{Metodologi}

Metode penelitian terdiri dari tiga bagian besar yaitu tahap pendahuluan, tahap implementasi model manajemen perubahan dan lean six sigma, serta tahap kesimpulan dan saran.

Tahap pendahuluan terdiri dari 5 aktivitas yaitu studi lapangan, penentuan topik, identifikasi masalah, studi literatur, dan sintesis penelitian.

Tahap implementasi penelitian merupakan penggabungan model manajemen perubahan dan lean six sigma. Model manajemen perubahan yang digunakan adalah model perubahan manajemen Kotter dan Lewin yang kedua metode tersebut digabungkan dengan metode DMAIC pada lean six sigma. Tabel 1 menunjukkan penggabungan metode manajemen perubahan dengan lean six sigma DMAIC.

Tabel 1. Penggabungan model manajemen perubahan dan metode DMAIC

\begin{tabular}{|c|c|c|c|c|c|c|}
\hline Lewin & Kotter & D & $\mathbf{M}$ & A & I & C \\
\hline \multirow[t]{3}{*}{$\begin{array}{l}\text { Un- } \\
\text { freezing }\end{array}$} & $\begin{array}{l}\text { Menumbuhkan } \\
\text { rasa urgensi }\end{array}$ & $\checkmark$ & $\checkmark$ & & & \\
\hline & $\begin{array}{l}\text { Menciptakan } \\
\text { koalisi pengarah }\end{array}$ & $\checkmark$ & & & & \\
\hline & $\begin{array}{l}\text { Membangun visi } \\
\text { dan strategi }\end{array}$ & $\checkmark$ & & $\sqrt{ }$ & & \\
\hline \multirow[t]{4}{*}{ Changing } & $\begin{array}{l}\text { Mengomunikasikan } \\
\text { visi yang telah } \\
\text { berubah }\end{array}$ & & & $\checkmark$ & $\checkmark$ & \\
\hline & $\begin{array}{l}\text { Pemberdayaan } \\
\text { pekerja }\end{array}$ & & & $\sqrt{ }$ & $\sqrt{ }$ & \\
\hline & $\begin{array}{l}\text { Membangkitkan } \\
\text { kemenangan } \\
\text { jangka pendek }\end{array}$ & & $\checkmark$ & & $\checkmark$ & \\
\hline & $\begin{array}{l}\text { Mengonsolidasikan } \\
\text { keuntungan lebih } \\
\text { lanjut }\end{array}$ & & & & $\checkmark$ & \\
\hline $\begin{array}{l}\text { Re- } \\
\text { freezing }\end{array}$ & $\begin{array}{l}\text { Menancapkan } \\
\text { pendekatan baru }\end{array}$ & & $\checkmark$ & & & $\checkmark$ \\
\hline
\end{tabular}

Dari Tabel 1 dapat dilihat bahwa sebenarnya penggabungan model manajemen perubahan secara definisi bersinggungan dengan lean six sigma DMAIC. Tahapan model perubahan Kotter ini memperlihatkan langkah-langkah metode perubahan yang lebih terperinci. Hal tersebut sesuai dengan metode DMAIC yang secara khusus memberikan tahapan dalam meraih keunggulan proyek perbaikan. 


\section{Unfreezing}

Pada tahapan ini tahap yang dilakukan bertujuan sebagai pencairan. Pencairan yang dimaksud adalah mengurangi resistensi yang ditimbulkan oleh lingkungan PT X, khususnya karyawan maupun pemimpin, dengan cara membuka pola pikir baru terhadap cara pandangan bekerja. Adapun langkah-langkah yang dilakukan seperti berikut:

a) Proses wawancara informal.

b) Mengidentifikasi aliran proses produksi PT $X$ dengan membuat value stream mapping, melihat waste yang dihasilkan akibat dari proses yang berlangsung, serta menghitung DPMO.

c) Membentuk tim agen perubahan.

d) Membentuk Visi dan Misi di PT $X$ menggunakan metode.

e) Mengidentifikasi penyebab terjadinya masalah kualitas

\section{Changing}

Pada tahapan ini tahap dimana seluruh pekerja diberikan informasi baru, cara pandang baru, serta mengatasi masalah baru dalam bekerja. Tahapan ini juga pekerja diberikan wewenang lebih dalam bekerja guna mengembangkan kemampuannya, seperti halnya ikut berperan aktif dalam melakukan improve atau perbaikan menggunakan metode brainstorming.

\section{Refreezing}

Tahapan ini berisikan tentang penguatan, pemberian motivasi secara penuh, membantu orang lebih menyesuaikan dengan kondisi yang baru. Kemudian tahap kesimpulan dan saran yang merupakan akhir dari proses penelitian.

\section{Hasil dan Diskusi}

Proses produksi di PT $X$ secara umum dimulai dari proses pemotongan, penyablonan, penjahitan hingga proses inspeksi.

Proses pemotongan masih dilakukan secara manual dibantu dengan mesin pemotong. Kain goni yang panjang dipotong sesuai dengan ukuran produk yang telah ditentukan, pengukuran pemotongan menggunakan penggaris meteran dan ditandai oleh spidol kemudian di potong dengan tanda dan ukuran yang telah dibuat, dalam proses ini terdiri dari 2 orang pekerja untuk menyelesaikan prosesnya.

Proses selanjutnya adalah penyablonan. Dalam proses ini terdapat 2 orang yang mengerjakannya. Sebelum dilakukan proses penyablonan, terlebih dahulu dilakukan pencetakan gambar menggunakan kertas kalkir yang ditransformasikan ke digital printing, hasil dari printing tersebut dicocokkan dengan ukuran kain goni, kemudian dibuatlah cetakan untuk proses sablon pada kain goni, hasil cetakan tersebut dikeringkan menggunakan dryer dan dibantu oleh sinar matahari.

Setelah memperoleh kain goni yang sudah terdapat gambar sablon, proses selanjutnya adalah penjahitan. Pada proses jahit terdapat 2 orang pekerja. Dalam proses ini juga dilakukan penambahan komponen lain seperti penambahan aksesoris sebagai penambah nilai estetika dari produk PT X.

Proses akhir dari proses produksi di PT $X$ adalah inspeksi. Proses ini terdiri dari menghilangkan serat dan sisa benang jahitan serta proses pembakaran menggunakan fire torch kemudian packing dan delivery.

\section{Unfreeze}

Fase ini merupakan fase eksplorasi dan perencanaan, didasarkan pada keputusan mengapa perlu membuat perubahan spesifik dalam operasi khususnya proses produksi di PT X.

Tahapan ini juga sangat penting dilakukan dalam proses perubahan, namun sebelum masuk ke tahap ini, perlu dilakukan wawancara. Wawancara ini dilakukan untuk mengetahui respons pemimpin dan pekerja melihat konsistensi dihasilkannya produk cacat. Wawancara ini penting karena setiap perubahan akan terjadi jika terdapat motivasi untuk berubah yang dimiliki oleh seluruh tim. Wawancara ini juga mengidentifikasi tingkat inisiatif para pekerja, khususnya pemimpin dalam memimpin perubahan. Pertanyaan yang diajukan kepada responden terdiri atas empat poin utama, yaitu:

- Apakah proses produksi untuk produk karung kopi, tas jinjing gambar, dan jinjing sudah sesuai dengan keinginan Anda.

- Jika ya, apa alasan ketidaksesuaian proses yang ada pada masing-masing produk tersebut. 
- Apakah hal-hal tersebut berpengaruh terhadap keuntungan perusahaan.

- Apakah Anda ingin mengubah ketidaksesuaian hal tersebut.

Setelah dilakukan proses wawancara informal terhadap seluruh responden yaitu pemimpin dan pekerja, diperoleh bahwa seluruh responden ingin mengubah ketidaksesuaian proses bekerja. Alasan-alasan seperti profit yang belum maksimal, tidak jelasnya instruksi kerja bahkan lingkungan kerja yang tidak baik banyak dikemukakan oleh responden. Dari hasil wawancara ini memperlihatkan bahwa penciptaan motivasi pekerja dan pemimpin sudah muncul untuk melakukan perubahan.

Untuk memperlihatkan bahwa PT X berada pada situasi krisis, perlu ditambahkan masalah yang terjadi di kegiatan proses produksi dengan cara identifikasi aliran proses. Proses identifikasi dalam penelitian ini menggunakan value stream mapping untuk ketiga produk yang diamati, kemudian persentase cacat, DPMO (defect per million opportunities) dan nilai sigma yang dihasilkan dari proses awal sebelum dam sesudah perbaikan dilakukan.

Rasa puas diri merupakan kesalahan umum yang sering terjadi dalam proses perubahan. Tabel 2 memperlihatkan bahwa proses produksi di PT $\mathrm{X}$ berada di kondisi krisis, bahkan jauh dari efektif dan efisien.

Tabel 2. Data proses produksi sebelum kondisi perubahan dan perbaikan

\begin{tabular}{|c|c|c|c|}
\hline Indikator & Tas jinjing & $\begin{array}{c}\text { Tas jinjing } \\
\text { gambar }\end{array}$ & $\begin{array}{c}\text { Karung } \\
\text { kopi }\end{array}$ \\
\hline VA & 6,96 jam & 7,20 jam & 6,69 jam \\
\hline NVA & 1,24 jam & 1,36 jam & 1,38 jam \\
\hline$\%$ Cacat & $19 \%$ & $29 \%$ & $32 \%$ \\
\hline DPMO & 65555,65 & 68250 & 80000 \\
\hline Nilai sigma & 3.010 & 2,989 & 2,945 \\
\hline
\end{tabular}

Situasi seperti ini akan berdampak positif bagi proses perubahan, karena tekanan untuk proses perubahan akan lebih besar selama lingkungan tersebut mengalami situasi krisis, atau dapat dikatakan bahwa waktu terbaik melakukan perubahan adalah pada saat terjadinya krisis.

Dalam menciptakan suatu perubahan yang signifikan akan sulit untuk dilakukan, oleh karena itu diperlukan dukungan dan motivasi besar guna menerapkan proses perubahan tersebut. Perlu adanya dukungan yang terarah atau tim koalisi pengarah kuat yang bertujuan mengarahkan perubahan yang direncanakan sehingga perubahan itu akan berdampak signifikan.

Berdasarkan hasil pengamatan awal pemimpin bertindak sebagai perencana, sedangkan pekerja bertugas sebagai pelaksana. Dalam situasi awal, kurangnya koordinasi dan komunikasi mengakibatkan ketidakjelasan instruksi kerja dan kurangnya pengawasan dalam bekerja. Padahal, manajemen perubahan akan optimal jika kemampuan komunikasi dilakukan secara efektif dan adanya komitmen terhadap pengembangan individu yang terlibat saat pengambilan keputusan untuk perubahan.

Menindaklanjuti hal tersebut dibuatlah tim koalisi pengarah yang terdiri dari pemimpin dan pengawas produksi. Pengawas produksi ini dipilih oleh pemimpin yang membantu memantau, memeriksa serta memberikan informasi atas segala perintah pimpinan terhadap kinerja lainnya. Pemimpin tim koalisi sebaiknya fokus dalam proses pengawasan dan rencana kerja. Namun pada hakikatnya pembentukan tim koalisi pengarah harus memiliki peran kritis dan aktif, oleh karena itu dalam membentuk tim koalisi pengarah disarankan lebih selektif pemilihannya, karena tidak semua karyawan PT $X$ memiliki peran yang dibutuhkan dalam pembentukan tim perubahan.

Setelah dibentuk tim koalisi pengarah selanjutnya adalah penentuan visi misi. Visi akan menggambarkan cita-cita, impian, tujuan di masa depan dari suatu organisasi atau perusahaan yang harus di capai, begitu pula misi merupakan strategi-strategi guna merealisasikan visi yang telah ditetapkan.

Visi dan misi ditetapkan berdasarkan hasil diskusi bersama, kualitas menjadi landasan utama dalam pembentukan visi. Dengan diskusi bersama, maka visi dan strategi organisasi ini diharapkan mampu menjadi pedoman pelaksanaan kegiatan proses produksi di PT $X$ yang dijalankan secara konsisten.

\section{Changing}

Setelah terbentuknya tim koalisi yang dipimpin oleh pemimpin PT $X$ dan beranggotakan satu orang sebagai tangan kanan pemimpin diharapkan dapat mempermudah proses komunikasi pemimpin 
terhadap bawahannya, salah satunya adalah mengkomunikasikan visi misi yang telah berubah, sehingga memiliki pemahaman visi dan strategi PT $X$ yang sama dalam mencapai tujuannya. Dalam penelitian ini juga dibuat aliran informasi sebagai bentuk komunikasi dengan media formulir guna untuk penunjang proses produksi seperti formulir target kerja dan rencana, formulir produk cacat, formulir inspeksi alat dan formulir produksi. Semua formulir memiliki fungsinya masing-masing dan diharapkan menjadi salah satu bentuk komunikasi secara tidak langsung dari pimpinan ke bawahannya.

Perbaikan dan perubahan akan berdampak signifikan jika semua terlibat dan berperan aktif secara umum dan luas. Aksi pemberdayaan karyawan secara luas berarti upaya untuk membuat karyawan menjadi lebih berdaya dan mendorong mereka menjadi lebih terlibat dalam pengambilan keputusan yang berkaitan dengan pekerjaannya.

Dalam proses perbaikan seluruh karyawan dan pemimpin berperan aktif guna membuat proses produksi lebih baik menjadi lebih efektif dan efisien. Berikut merupakan peranan seluruh responden yang di bagi berdasarkan divisi proses produksi terhadap perbaikan proses produksi di PT $X$ melalui metode brainstorming.

Berdasarkan Tabel 3 dapat dilihat bahwa seluruh karyawan yang terlibat lebih berdaya lebih dapat menuangkan gagasannya untuk menjadi kenyataan, hal ini akan menimbulkan meningkatkan motivasi atau rasa kepemilikan yang lebih atas raihan pekerjaan yang mereka lakukan.

Setelah berbagai perbaikan dilakukan serta diimplementasikan, berikutnya adalah memberi keyakinan serta kepastian atas bukti keberhasilan raihan yang telah dicapai. Bukti atas raihan pencapaian ini dapat dilihat di Tabel 4.

Berdasarkan Tabel 4 dapat dilihat bahwa performansi proses untuk semua produk yang diamati di PT $\mathrm{X}$ lebih baik jika dibandingkan kondisi sebelum perubahan dan perbaikan. Meskipun nilai NVA cenderung bertambah tapi jam kerja karyawan cenderung menurun atau berjalan normal. Normal yang dimaksud adalah karyawan atau pekerja tidak mengalami jam lembur dalam melakukan kegiatan proses produksi. Kemenangan jangka pendek tidak hanya membawa dampak positif untuk moral pemimpin dan pekerja saja, tetapi PT X juga merasakan akan keuntungannya, contoh bentuk keuntungannya dapat dilihat dalam Tabel 4, seperti rasio cacat yang berkurang dan nilai sigma yang bertambah. Namun perubahan yang benar-benar nyata tidak terjadi dalam waktu yang singkat. Kemenangan jangka pendek hanya merupakan tahap awal dari apa yang perlu dilakukan untuk mencapai perubahan jangka panjang, maka dari itu sangatlah penting untuk terus mengonsolidasikan keuntungan atau keberhasilan jangka pendek sebagai catatancatatan dari setiap proses perubahan ke arah yang lebih baik lagi.

Tabel 3. Peranan seluruh karyawan terhadap perbaikan proses produksi di PT X

\begin{tabular}{|c|l|}
\hline Jabatan & $\begin{array}{c}\text { Peran aktif dalam perbaikan proses } \\
\text { produksi }\end{array}$ \\
\hline Pemimpin & $\begin{array}{l}\text { Merumuskan dan } \\
\text { mengimplementasikan hal-hal yang } \\
\text { dapat meningkatkan keefektifan dan } \\
\text { efisien kegiatan produksi }\end{array}$ \\
\hline $\begin{array}{c}\text { Operator } \\
\text { cutting }\end{array}$ & $\begin{array}{l}\text { Merancang stasiun kerja cutting yang } \\
\text { baik agar kinerja pekerja efektif }\end{array}$ \\
\hline $\begin{array}{c}\text { Operator } \\
\text { sablon }\end{array}$ & $\begin{array}{l}\text { Memberikan ide mengenai } \\
\text { pembuatan formulir kegiatan proses } \\
\text { produksi }\end{array}$ \\
\hline $\begin{array}{c}\text { Operator } \\
\text { jahit }\end{array}$ & $\begin{array}{l}\text { Memberikan ide mengenai } \\
\text { pengecekan jarum secara berkala dan } \\
\text { tata letak alat proses jahit }\end{array}$ \\
\hline $\begin{array}{l}\text { Operator } \\
\text { finishing }\end{array}$ & $\begin{array}{l}\text { Memberi gagasan dalam pembuatan } \\
\text { prosedur kerja di proses finishing }\end{array}$ \\
\hline
\end{tabular}

Tabel 4. Data proses produksi untuk semua produk setelah kondisi perubahan dan perbaikan

\begin{tabular}{|c|c|c|c|}
\hline $\begin{array}{c}\text { Indikator } \\
\text { performa } \\
\text { proses }\end{array}$ & Tas jinjing & $\begin{array}{c}\text { Tas jinjing } \\
\text { bergambar }\end{array}$ & $\begin{array}{c}\text { Karung } \\
\text { Kopi }\end{array}$ \\
\hline VA & 6,67 jam & 6,91 jam & 6,67 jam \\
\hline NVA & 1,36 jam & 1,55 jam & 1,26 jam \\
\hline$\%$ Cacat & $13 \%$ & $18 \%$ & $14 \%$ \\
\hline DPMO & 49167 & 55039 & 53498 \\
\hline $\begin{array}{c}\text { Nilai } \\
\text { sigma }\end{array}$ & 3,20 & 3,06 & 3,19 \\
\hline
\end{tabular}

Pada dasarnya fase ini adalah mengimplementasikan perubahan yang ditarik dari berbagai perencanaan di fase sebelumnya. Proses perubahan yang menyangkut desain untuk menggerakkan organisasi dari keadaan sekarang yaitu keadaan dimana banyak dihasilkannya waste menuju ke keadaan yang akan datang atau yang diharapkan yaitu memproduksi sedikit waste. 
Keadaan sekarang mewajibkan bahwa setiap individu aktif terlibat dalam mengupayakan perubahan, setiap individu mempunyai porsi dan peranan penting atas dicetuskannya suatu proses perubahan. Berdasarkan Tabel 3 dapat dilihat bahwa setiap individu memiliki peranan dan tanggungan jawab untuk ikut aktif melakukan suatu perubahan. Proses perubahan mengerucut ke bagian sub proses paling terkecil untuk satu tujuan yaitu visi yang telah ditetapkan. hal ini menandakan bahwa setiap individu lebih berdaya, keberdayaan setiap para pekerja ditandai dengan keterlibatan mereka. Proses perubahan yang baik akan menghasilkan lingkungan yang baik dan akan berdampak bagi karyawan juga PT $X$ itu sendiri.

\section{Refreezing}

Setelah dilakukan proses perbaikan dan perubahan terhadap proses produksi tas jinjing, tas jinjing bergambar dan karung kopi, harus diakui bahwa kondisi pada saat ini adalah kondisi yang sangat mudah kembali untuk berubah atau disebut kondisi rawan. Perlu adanya tindakan-tindakan khusus guna menciptakan sesuatu yang berkaitan dengan budaya organisasi. Adapun strategi-strategi yang diusulkan guna menytabilisasi kondisi perusahaan serta karyawan pada saat proses perubahan telah dilakukan, dan berikut usulannya:

- Pemberian pelatihan serta pengetahuan secara berkala guna peningkatan efektivitas kinerja para pekerja

- Evaluasi secara berkala yang dilakukan oleh pemimpin guna penciptaan standar kinerja perusahaan

- Melakukan kegiatan yang dapat mengupayakan hubungan antara pekerja maupun pemimpin terjalin, sehingga menciptakan bonding yang sangat kuat.

Selain bentuk usulan yang diusulkan, tahapan akhir yang dilakukan peneliti dalam proses perubahan adalah wawancara, sebagai bentuk evaluasi setelah terjadinya perubahan dan perbaikan di PT $X$. Berikut merupakan poin pertanyaan yang ditanyakan:
1. Proses perubahan dan perbaikan yang berlangsung berdampak signifikan terhadap kepuasan kinerja Anda.

2. Apakah proses perubahan dan perbaikan yang selama ini berlangsung memberikan banyak keuntungan bagi perusahaan.

3. Apakah proses perubahan dan perbaikan yang selama ini berlangsung memberikan banyak keuntungan bagi Anda sendiri.

4. Jika suatu waktu Anda didesak untuk melakukan suatu perubahan yang berdampak terhadap perbaikan proses produksi di PT X, apakah Anda siap.

Pertanyaan-pertanyaan tersebut ditanyakan kepada seluruh responden yaitu seluruh karyawan dan pemimpin PT $X$, guna sebagai evaluasi pada tahapan refreezing, dan berikut merupakan hasil wawancaranya yang dapat dilihat pada Tabel 5 di bawah ini.

Tabel 5. Evaluasi tahapan refreezing

\begin{tabular}{|c|c|c|c|c|}
\hline \multirow{2}{*}{ Jabatan } & \multicolumn{4}{|c|}{ Pertanyaan evaluasi tahap refreeze di } \\
& \multicolumn{4}{|c|}{ PT X } \\
\cline { 2 - 5 } & $\mathbf{1}$ & $\mathbf{2}$ & $\mathbf{3}$ & $\mathbf{4}$ \\
\hline Pemimpin & $\mathrm{Ya}$ & $\mathrm{Ya}$ & $\mathrm{Ya}$ & $\mathrm{Ya}$ \\
\hline Cutting & $\begin{array}{c}\text { Tidak } \\
\text { tahu }\end{array}$ & $\mathrm{Ya}$ & Tidak & Tidak \\
\hline Cutting & $\mathrm{Ya}$ & $\mathrm{Ya}$ & $\mathrm{Ya}$ & $\mathrm{Ya}$ \\
\hline Sablon & $\begin{array}{c}\text { Tidak } \\
\text { tahu }\end{array}$ & $\mathrm{Ya}$ & Tidak & $\mathrm{Ya}$ \\
\hline Sablon & $\mathrm{Ya}$ & $\mathrm{Ya}$ & $\mathrm{Ya}$ & $\mathrm{Ya}$ \\
\hline Jahit & $\mathrm{Ya}$ & $\mathrm{Ya}$ & $\mathrm{Ya}$ & $\mathrm{Ya}$ \\
\hline Jahit & $\mathrm{Ya}$ & $\mathrm{Ya}$ & $\mathrm{Ya}$ & $\mathrm{Ya}$ \\
\hline Inspeksi & $\mathrm{Ya}$ & $\mathrm{Ya}$ & $\mathrm{Ya}$ & $\mathrm{Ya}$ \\
\hline Inspeksi & $\mathrm{ya}$ & $\mathrm{Ya}$ & $\mathrm{Ya}$ & $\mathrm{Ya}$ \\
\hline
\end{tabular}

Berdasarkan Tabel 5 mayoritas keseluruhan karyawan PT $X$ merasakan dampak positif akibat proses perubahan dan perbaikan yang berlangsung dengan baik. Pekerja cutting dan sablon yang menjawab "tidak" pada beberapa pertanyaan merupakan pekerja yang perlu ditingkatkan peran dan partisipasinya untuk memberi dampak yang lebih baik.

Ketika kebutuhan yang telah terpenuhi dengan melihat tahapan sebelumnya, serta mendapatkan raihan dampak positif atas proses perubahan dan perbaikan yang telah dilakukan, kemudian sebaiknya dibekukan atau ditetapkan. Fase ini merupakan keadaan yang diharapkan dalam fase perencanaan atau unfreeze. Kegiatan proses produksi yang sudah lebih baik dari sebelumnya seharusnya 
menjadi standar atau awalan untuk melanjutkan pola yang lebih baik lagi.

Pada umumnya dalam fase ini berisikan tentang memperkuat usaha-usaha yang telah dilakukan dikuatkan kembali. Hal ini akan seperti menjaga serta melanjutkan momentum yang sudah terjalin berlangsung baik pada proses perubahan. Namun fase ini juga seperti yang dibahas sebelumnya merupakan kondisi rawan, maka dari itu jika tidak dijaga dan dipelihara besar kemungkinan setiap individu untuk kembali pada metode dan perilaku sebelumnya. Terdapat dua usaha yang seharusnya dilakukan pemimpin untuk menjaga momentum ini yaitu memberikan dukungan penuh pada tim koalisi perubahan dan membantu karyawan lebih menyesuaikan dengan kondisi yang sekarang, karena dalam evaluasi tahapan ini terdapat beberapa orang yang memiliki tingkat resistensi tinggi dapat dilihat pada Tabel 5, individu-individu seperti itu perlu perlakukan khusus sehingga untuk menjalankan misi demi tercapainya visi yang ditetapkan.

Bagi usaha kecil seperti PT $X$, upaya melakukan manajemen perubahan bukan hal yang mudah. Peningkatan partisipasi karyawan di tingkat operator memerlukan pendekatan yang terus menerus dengan menekankan manfaat bagi karyawan sendiri. Pentingnya pendampingan oleh tim koalisi dan bukti nyata bagi para karyawan itu sendiri bisa menjadi momentum perbaikan yang dapat bersifat jangka panjang.

\section{Kesimpulan}

Berdasarkan hasil dan pembahasan dapat ditarik kesimpulan sebagai berikut:

1. Hal-hal yang berpengaruh dalam penerapan manajemen perubahan terhadap proyek perbaikan lean six sigma adalah menciptakan rasa urgensi, membentuk tim koalisi, membangun visi dan misi, mengomunikasikan visi, pemberdayaan pekerja, membangkitkan kemenangan jangka pendek, mengonsolidasikan keuntungan, dan menancapkan pendekatan baru ke dalam budaya.

2. Pada proses penerapan manajemen perubahan di dalam proyek perbaikan lean six sigma DMAIC, masih terdapat jenis pemborosan, salah satu di antaranya adalah defect yang menjadi fokus utama perbaikan pada proyek lean six sigma.

3. Proses perubahan dan perbaikan yang berlangsung memberikan dampak positif bagi karyawan dan PT $X$ itu sendiri. Perbandingan performa proses produksi setelah perubahan dan perbaikan lebih baik jika dilihat dari nilai value added, non value added, persentase cacat, nilai DPMO dan nilai sigma.

\section{Daftar Pustaka}

Arneither, E.D., \& Maleyeff, J. (2005). The Integration of Lean Management and Six Sigma. The TQM Magazine, 17(1), 5-8.

Gupta, P. (2011). Leading Innovation Change The Kotter Way. International Journal of Innovation Science, 3, 141-149.

Hess, J. D., \& Benjamin, B. A. (2015). Applying Lean Six Sigma within the University: Opportunities for Process Improvement and Cultural Change. International Journal of Lean Six Sigma, 6(3), 249-262.

Hudnurkar, M., Ambekar, S., \& Bhattacharya, S. (2019). Empirical analysis of Six Sigma Project Capability Deficiency and Its Impact on Project Success. The TQM Journal, 31(3), 340-358.

Kotter, J.P. (1996). Leading Change. Boston: Harvard Business School Press.

Lertwattanapongchai, S. \& Swierczek, F.W. (2016). Assesing the Change Process of Lean Six Sigma. International Journal of Lean Six Sigma, 5(4), 423-443.

Noori, B., \& Latifi, M. (2018). Development of Six Sigma Methodology to Improve Grinding Processes: A Change Management Approach. International Journal of Lean Six Sigma, 9(1), 50-63.

Pepper, M., \& Spedding, T. (2010). The Evolution of Lean Six Sigma. International Journal of Quality and Reliability Management, 27(2), 138-298.

Pyzdek, T. (2003). The Six Sigma Handbook Revised and Expanded. McGraw-Hill.

Robbins, S.P. (2001). Organizational Behaviour. New Jersey: Prentice Hall International.

Salah, S., Rahim, A., \& Carretero, J, A. (2010). The Integration of Six Sigma and Lean Management. International Journal of Lean Six Sigma, 1(3), 249-274. 